\title{
生態系モデルを用いた東京湾夏季の水質シミュレーション
}

Numerical Simulation of Water Quality in Tokyo Bay in Summer using Biological model

田中昌宏* ·稲垣 聡*

Masahiro Tanaka and Satoshi Inagaki

\begin{abstract}
A biological model has been developed to simulate the water quality in a bay. The model is a hydrodynamical and ecological coupled model, and the ecological model includes the biological process in the bottom sediment. The vertical diffusivity is estimated by $\mathrm{k}-\varepsilon$ turbulence model to simulate the vertical transport process with high accuracy. The model was applied to Tokyo Bay in summer, which is a typical eutrophicated bay in Japan. The numerical results showed good agreement with the observed data. The model can simulate the formation of oxygen poor water in the bottom layer, which is the most serious environmental problem in Tokyo Bay
\end{abstract}

Keywords : biological model, numerical simulation, eutrophication,, oxygen poor water

1.はじめに

東京湾は我が国の富栄養化が進んだ典型的な内湾であり、環境基準を達成するため様々な努力が払われている。 その一方で、埋め立てを中心とした開発プロジェクトも数多く計画されているが、今後のプロジェクト推進にあ たっては、従来のようなその影響を最小限に食い止めるだけでは不十分であり、より積極的にプロジェクトの一 環として豊かな環境を新たに創造することが要求されている。こうしたニーズに対応するために、数值モデルを 用いた海域の生態環境のシミュレーションが有力なツールとして使用されはじめている。

Nakata and Kuramoto(1992)は、無機一有機栄養塩循環を基本としたモデルを構築し、東京湾の最も深刻な環境 問題である底層の貧酸素水塊の形成をシミニレートし、その中で鉛直方向の拡散係数が重要なパラメータである ことを指摘している。一方堀口・中田(1995) は、動物プランクトンを含む生態系モデルを構築し、東京湾夏季の 水質シミュレーションを行っている。このシミュレーションでは、COD、総窒素、総リンに関しては実測值と良好 な一致をみたが、プランクトン量や栄養塩つ結果には問題があり、その原因について詳細な検討を行っている。

このように、東京湾の生態系シミュレーションに関しては、まだ多くの問題が残されおり、様々な角度からの 検討が必要である。そこで、本研究では東京湾の現状の水質環境を再現できるモデルの開発を目指し、夏季の平 均的な水質のシミュレーションを行った。

\section{2. 生態系モデル}

モデルは、オランダ・デルフト水理研究所が開発し、共同 で改良を加えている流れ解析モデル TRISULA と水質解析モ デル DELWAQを使用した。著者ら(1996)は、これらのモデル を用いて東京湾の残差流とそれが水質解析に及ほす影響につ いて検討しており、本論文では、水質モデルをさらに高度化 し、植物プランクトンまでを含む生態系モデルを作成した。 また、貧酸素水塊の再現にとって重要である鉛直拡散係数を 高精度に求めるため、流れ解析に用いた $\mathrm{k}-\varepsilon$ モデルから求め られた值を水質解析にも用いた。

\section{1 モデルの構成}

モデルの全体構成を図 1 に示す。大きく浮遊系と底泥系に 分かれ、浮遊系は植物プランクトンを中心として、炭素、窒 素、リン及び溶存酸素の循環がモデル化されている。底泥系 は、有機態物質の浮遊系における移流拡散過程以外のすべて

* 正会員 鹿島技術研究所第 1 研究部第 4 研究室 干182 東京都調布市飛田給 2-19-1

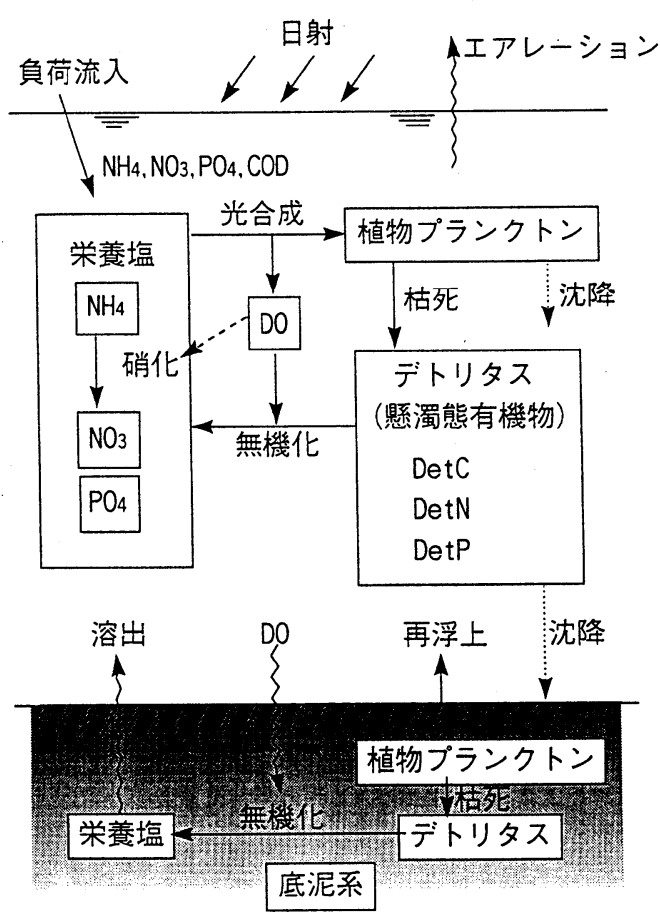

図 1 生態系モデルの構成 
の過程がモデルかされている。ただし底泥内の溶存物質はモデル化されていないため、底泥内の有機物の反応は 浮遊系の最底層の溶存物質との間で生じることになる。モデル変数をまとめると表 1 のようになる。

2.2 基礎方程式

モデルの基礎方程式は次式で与えられる。

$\frac{\partial C}{\partial t}-\frac{\partial}{\partial x}\left(D_{x} \frac{\partial C}{\partial x}-u C\right)-\frac{\partial}{\partial y}\left(D_{y} \frac{\partial C}{\partial y}-v C\right)-\frac{\partial}{\partial z}\left(D_{z} \frac{\partial C}{\partial z}-w C\right)=F(C)$

ここに、C ; 各変数の濃度、 $\mathrm{t}$; 時間、 $\mathrm{x} 、 \mathrm{y}$; 水平方向座標、 $z$;

鉛直方向座標、Dx、Dy、Dz; 各方向の拡散係数、 $\mathrm{u} 、 \mathrm{v} 、 \mathrm{w}$; 各方向 の流速、 $\mathrm{F}(\mathrm{C})$; 生化学反応項である。

化学反応の項を変数毎に示すと以下のようになる。

$\mathrm{F}(\mathrm{Green})=($ 光合成による增殖 $)-($ 呼吸 $)-($ 死亡 $)-($ 沈降 $)$

$\mathrm{F}(\operatorname{DetC}, N, P)=($ 植物プランクトンの死亡 $)-($ 無機化 $)-($ 沈降 $)$

$\mathrm{F}\left(\mathrm{NH}_{4}-\mathrm{N}\right)=($ デトリタスの無機化 $)+($ 植物プランクトンの死亡 $)$

一(光合成による摂取) - (硝化) +(底泥からの溶出)

$\mathrm{F}\left(\mathrm{NO}_{3}-\mathrm{N}\right)=($ デトリタスの無機化 $)+($ 植物プランクトンの死亡 $)$

- (光合成による摂取 $)+($ 硝化 $)-($ 脱窒 $)+($ 底泥からの溶出 $)$

$\mathrm{F}\left(\mathrm{PO}_{4}-\mathrm{P}\right)=($ デトリタスの無機化 $)+($ 植物プランクトンの死亡 $)$

-(光合成による摄取 $)+($ 底泥からの溶出 $)$

表 1 モデル変数

\begin{tabular}{|c|c|c|c|}
\hline & 水質指標 & 変数名 & 単位 \\
\hline \multirow{3}{*}{ 浮 } & 植物プランタト & Green & $\mathrm{gC} / \mathrm{m}^{3}$ \\
\hline & デトリタ久炭素 & DetC & $\mathrm{gC} / \mathrm{m}^{3}$ \\
\hline & デトリタス窒素 & $\operatorname{DetN}$ & $\mathrm{gN} / \mathrm{m}^{3}$ \\
\hline \multirow[t]{2}{*}{ 遊 } & デトリタスリン & DetP & $\mathrm{gP} / \mathrm{m}^{3}$ \\
\hline & アソモニア態窒素 & $\mathrm{NH}_{4}-\mathrm{N}$ & $\mathrm{gN} / \mathrm{m}^{3}$ \\
\hline \multirow[t]{3}{*}{ 系 } & 硝酸態窒素 & $\mathrm{NO}_{3}-\mathrm{N}$ & $\mathrm{gN} / \mathrm{m}^{3}$ \\
\hline & リン酸態リン & $\mathrm{PO}_{4}-\mathrm{P}$ & $\mathrm{gP} / \mathrm{m}^{3}$ \\
\hline & 溶存酸素 & OXY & $\mathrm{g} / \mathrm{m}^{3}$ \\
\hline 底 & 植物プランクトン & GreenS & $\mathrm{gC} / \mathrm{m}^{3}$ \\
\hline 泥 & デトリ夕久炭素 & DetCS & $\mathrm{gC} / \mathrm{m}^{3}$ \\
\hline \multirow[t]{2}{*}{ 系 } & デトリ夕人窒素 & DetNS & $\mathrm{gN} / \mathrm{m}^{3}$ \\
\hline & デトリタスリン & DetPS & $\mathrm{gP} / \mathrm{m}^{3}$ \\
\hline
\end{tabular}

$\mathrm{F}($ GreenS $)=($ 死亡 $)$

$\mathrm{F}($ DetCS,NS,PS $)$ = (植物プランクトンの死亡) - (無機化)

各反応及び変数は表 2 及び表 3 にまとめた。

\section{3. 計算条件}

計算メッシュは図 2 に示すように、一辺 $800 \mathrm{~m}$ の正方形メッシュとし、鉛直方向には $\sigma$ 座標系で、流動計算は 10 層、水質解析は 5 層とした。

流動解析は、夏季の平均的な流れ場(残差流)を求めるため、湾口で潮汋(M2 分潮)を与え、主要河川から淡水の 供給を与え、定常に達する(30日)まで計算した。計算の詳細 は田中ら(1996)を参照されたい。

水質解析における初期条件、境界条件、流入負荷量及び各 種パラメータの值は、堀口・中田(1995)にほぼ従って与えた。 それぞれを表 4 から表 7 に示す。この条件の下に計算を 60 日 間行った。

\section{4. 結果及び考察}

水質解析に使用した流れ場は田中ら(1996)の CASE3 である。 この計算では、鉛直拡散係数の評価に $\mathrm{k}-\varepsilon$ 乱流モデルを使 用しており、水質解析にもそこで求まった拡散係数を使用し ている。

図 3 に湾中央部での表層の植物プランクトン及び栄養塩の 計算開始からの時系列を示す。どれも 60 日めではまだ完全に 定常に達していないが、变化の速度はかなり小さくなってお り、計算結果は初期条件の影響はほほなくなったと判断でき る。堀口・中田(1995)は 100 日程度で定常に達することを確認 しているが、ここでは計算時間の制約から 60 日目の結果につ いて考察する。

図 4 は 1994 年の公共用水域データによる 7 月のクロロフィ ル a 及び表層、底層の溶存酸素の值を示している。図 5 に計 算結果の内、表層の植物プランクトン、栄養塩、溶存酸素及 び底層の溶存酸素量を示す。堀口・中田によると東京湾にお

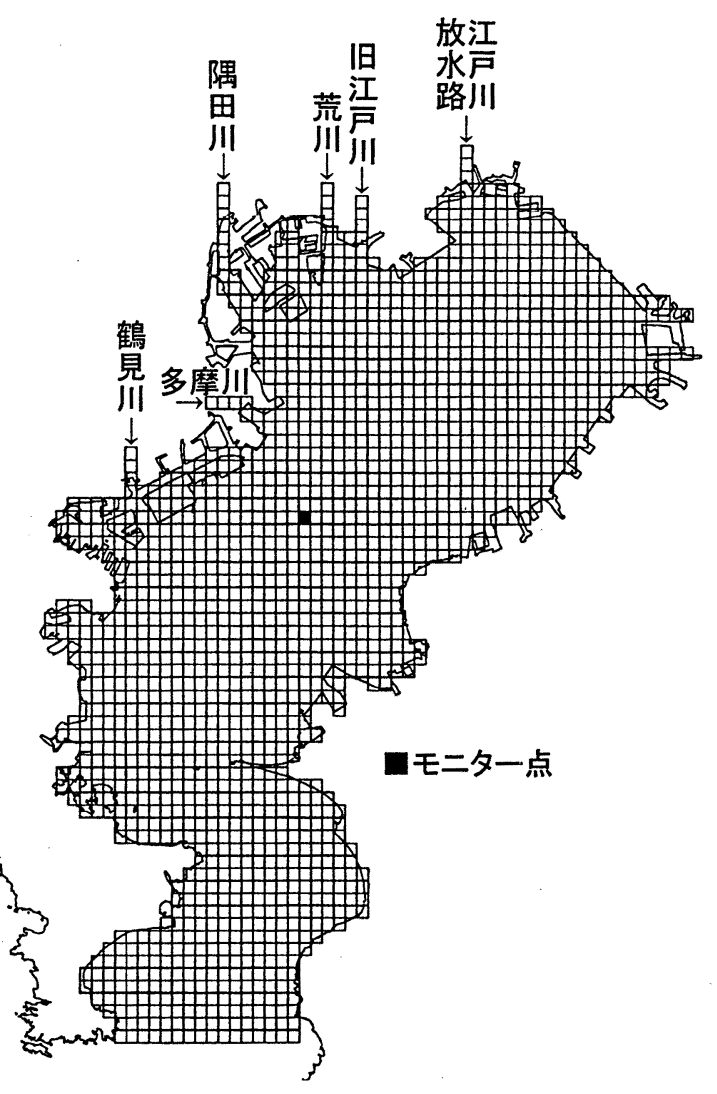

図 2 計算メッシュ 
けるクロロフィル/炭素比は、約 50 と報告されている。この比を適用すると、実測のプランクトン量は $1 \mathrm{gC} / \mathrm{m}^{3}$ 以上であり、計算結果と対応している。実測値は、湾西南岸の川崎から横須賀沖にかけて高い値を示しており、 計算結果と異なっている。これは、計算では流入負荷の設定を湾奥の主要河川のみにしか行っていないことが影 響しているものと考えられる。実測の溶存酸素は、表層ではクロロフィルaの高い領域で非常に高く過飽和の状 況になっている。計算結果もプランクトンの高濃度な領域で高くなっており、光合成に伴う酸素の生成に対応し ているものと考えられる。一方、底層の浴存酸素は、実測值、計算值共に湾奥で $2 \mathrm{~g} / \mathrm{m}^{3}$ 以下となっており、広い 範囲で貧酸素水塊が形成されている。この筫酸素水塊の形成は東京湾の最も深刻な環境問題であり、本モデルは その特性をよく再現していることがわかる。

表 2 生態系モデルの各反応式

(1) 浮遊系の植物プランクトンの増殖、呼吸及び死亡 $\mathrm{dPP}=($ RcGro $-\mathrm{RcMrt}) \times \mathrm{Green}$ $\mathrm{dMrt}=$ Mort $0 \times \mathrm{TFMrt} \times$ Green

RcGro $=$ LimDL $\times$ LimNut $\times$ LimRad $\times$ TFGro $\times$ PPMax RcMrt $=$ RcGro $\times$ Gresp + Mresp $\times$ TFMrt $\times(1-$ Gresp $)$

(2) 温度関数

TFGro $=$ TCGro $^{\text {Temp-20 }}$

$\mathrm{TFMrt}=\mathrm{TCDec}^{\text {Temp-20 }}$

（3）日長の制限関数

LimDL $=\operatorname{Min}($ DayL $、$ OptDL $) / O p t D L$

(4) 栄養塩の制限関数

LimNUT $=\operatorname{Min}(\operatorname{LimN} 、 \operatorname{LimP})$

$\mathrm{LimN}=\mathrm{DIN} /(\mathrm{DIN}+\mathrm{KmDIN})$

LimP $=\mathrm{PO} 4 /(\mathrm{PO} 4+\mathrm{KmP})$

$\mathrm{DIN}=\mathrm{NH} 4+\mathrm{NO} 3 / \mathrm{PrfNH} 4$

(5) 光の制限関数

RADsat $=$ TFGro $\times$ RADsat

RADbot $=$ RAD $\times$ EXP $[-$ ExtVL $\times$ Depth $]$

if $\frac{R A D}{R A D s a t}>1.0 \wedge \frac{R A D b o t}{R A D s a t}>1.0$ then

$\operatorname{LimRAD}=1.0$

if $\frac{R A D}{R A D s a t}>1.0 \wedge \frac{R A D b o t}{R A D s a t}<1.0$ then

LimRAD $=\frac{1+\ln \left(\frac{R A D}{R A D s a t}\right)-\left(\frac{R A D}{R A D s a t}\right) \times E X P[-E x t V L \times D e p t h]}{E x t V L \times \text { Depth }}$

if $\frac{R A D}{R A D s a t}<1.0$ then

$\operatorname{LimRAD}=\frac{R A D}{R A D s a t} \times \frac{(1-E X P[-E x t V L \times D e p t h])}{E x t V L \times D e p t h}$

(6)光合成による栄養塩の摂取

$\mathrm{dNH} 4 \mathrm{Upt}=\mathrm{dPP} \times \mathrm{NCRat} \times \mathrm{FracUptNH} 4$

$\mathrm{dNO} 3 \mathrm{Upt}=\mathrm{dPP} \times \mathrm{NCRat} \times(1-$ FracUptNH4 $)$

$\mathrm{dPO} 4 \mathrm{Upt}=\mathrm{dPP} \times \mathrm{PCRat}$

If $(N H 4<N H 4$ Krit $)$ :

$$
\begin{aligned}
& \text { FracUptNH } 4=\frac{N H 4}{N H 4+N O 3} \\
& \text { else } \\
& \text { If }(N H 4-N H 4 \text { Krit })>\operatorname{Re} q D I N: \\
& \quad \text { FracUptNH4 }=1.0 \\
& \text { If }(N H 4-N H 4 \text { Krit }<\text { Re } q D i n): \\
& \text { FracUptNH4 }=
\end{aligned}
$$

$\frac{(N H 4-N H 4 K r i t)+\left(\frac{N H 4 K r i t}{N O 3+N H 4 K r i t}\right) \times(\operatorname{Re} q D I N-N H 4+N H 4 K r i t)}{\operatorname{Re} q D I N}$
(7)植物プランクトンの死亡による栄養塩の放出 $\mathrm{dNH} 4 \mathrm{Aut}=\mathrm{dMrt} \times \mathrm{NCRat} \times$ FrAut

$\mathrm{dPO} 4 \mathrm{Aut}=\mathrm{dMrt} \times \mathrm{PCRat} \times$ FrAut

$\mathrm{dMortDetC}=\mathrm{dMrt} \times$ FrDet $/(1$-FrAut $)$

$\mathrm{dMortDetN}=\mathrm{dMrt} \times \mathrm{NCRat} \times$ FrDet

$\mathrm{dMortDetP}=\mathrm{dMrt} \times$ PCRat $\times$ FrDet

(8)硝化

アンモニアの硝化に対して

If Temp $<$ CTNit then

$\mathrm{dNitif}=\mathrm{ZNit}$

else

$\mathrm{dNitif}=$ Znitrif $+(\mathrm{RcNit} \times \mathrm{NH} 4 \times \mathrm{TempC} \times \mathrm{O} 2 \mathrm{FuncNit})$

TempC $=$ TcNit $^{\text {Temp }-20}$

溶存酸素に対して

if $O X Y \geq O O X N i t$ then

O2FuncNit $=1$

if $O X Y \leq O O X N i t$ then

O2FuncNit $=$ CFLNit

else

O2FuncNit $=(1-$ CFLNit $) \times\left(\frac{\text { OXY }- \text { COXNit }}{\text { OOXNit }- \text { COXNit }}\right)^{10^{\text {Cantur }}}+$ CFLNit

(9) 脱窒

If Temp $<$ CTDen then

$\mathrm{dDenWat}=\mathrm{ZDenWat}$

else

$\mathrm{dDenWat}=$ ZdenWat $+($ RcDenWat $\times$ NO3 $\times$ TempC $\times$ O2FUNC $)$ 温度関数

酸素関数

TempC $=T c D e n W a t^{\text {Tenp }-20}$

if $O X Y<O O X D E N$ then

O2FUNC -1

else

$O 2 F U N C=\frac{C O X D E N-O X Y}{C O X D E N-O O X D E N+\text { Curvt }^{\prime}(O X Y-O O X D E N)}$

(10) 分解

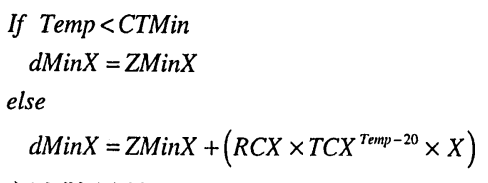

(11) 消散係数

ExtVL $=$ ExtVLBak + ExtVLOSS + ExtVLAlg

ExtVLOSS $=$ ExtVLDetC $\times$ DetC、 ExtVLAlg $=$ ExtVLGreen $\times$ Green 
表 3 生態系モデルの変数一覧

\begin{tabular}{|c|c|c|}
\hline $\begin{array}{l}\mathrm{dPP} \\
\text { ネットの増殖率 }\end{array}$ & RADsat プランクトンの飽和放射量 & Temp 水温 \\
\hline $\mathrm{dMrt}$ 死亡率 & ExtVL 可視光の消散係数 & 02FuncNit 硝化に関する酸素関数 \\
\hline RcGro 増殖率 & Depth 計算セグメントの厚さ & COXNit 臨界酸素濃度 \\
\hline RcMrt 呼吸速度 & dNH4Upt アンモニア摂取フラックス & 00XNit 最適酸素濃度 \\
\hline LimDL 日長の制限関数 & dN03Upt 硝酸摂取フラックス & CFLNit 酸素関数 \\
\hline LimNut 栄養塩の制限関数 & dP04Upt りん酸摂取フラックス & CurvNit 関数曲線パラメータ \\
\hline LimRad 光の制限関数 & NCRat 植物プランクトの窒素・炭素比 & dDenWat 脱窒フラックス \\
\hline TFGro 増殖の温度関数 & PCRat 植物プランクトンのリン・炭素比 & ZDenWat 0 次の脱窒速度 \\
\hline PPMax 最大増殖率 & FracüptNH4 アンモニアの消費比率 & RcDenWat 1 次の脱窒速度 \\
\hline Gresp 増殖に伴う呼吸ファクター & NH4Krit アンモニアの臨界濃度 & COXDEN＼cjkstart臨界酸素濃度 \\
\hline Mresp 呼吸速度 & dNH4Aut アンモニアの自己分解フラックス & OODEN 最適酸素濃度 \\
\hline TFMrt 死亡の温度関数 & dP04Aut りん酸の自己分解7ラックス & Curvat 酸素関数曲線パラメータ \\
\hline Mort0 死亡率定数 & dMortDetC DetC の死亡フラックス & X DetC、DetN、DetP \\
\hline TCGro 増殖に関する温度係数 & dMortDetN DetN の死亡フラックス & $\mathrm{dMinX}$ 分解物の総量 \\
\hline TCDec 死亡に関する温度係数 & dMortDetP DetP の死亡フラックス & 0 次の分解速度 \\
\hline DayL 日長 & FrAut 死亡に伴う自己分解の割合 & $\mathrm{RCX} 1$ 次の分解速度 \\
\hline OptDL 最適日長 & FrDet 死亡に伴うデトリ恀生成割合 & TCX 分解速度係数 \\
\hline KmDIN 窒素に対する半飽和定数 & dNitif アンモニアの硝化フラックス & CTMin 臨界温度 \\
\hline $\mathrm{KmP}$ リンに対する半飽和定数 & Znit 0 次の硝化フラックス & ExtVLBak バックグラウンドの消散係数 \\
\hline PrfNH4 アンモニアを好む率 & RcNit $20^{\circ} \mathrm{C}$ における反応速度定数 & \\
\hline RAD 計算セグメント上端にの放射量 & TcNit 温度係数 & \\
\hline
\end{tabular}

表 4 初期条件

\begin{tabular}{|l|l|}
\hline \multicolumn{1}{|c|}{ 変数 } & \multicolumn{1}{|c|}{ 值 } \\
\hline Green & $0.5\left(\mathrm{gC} / \mathrm{m}^{2}\right)$ \\
Det C & $0.8\left(\mathrm{gC} / \mathrm{m}^{3}\right)$ \\
Det $\mathrm{N}$ & $0.128\left(\mathrm{gN} / \mathrm{m}^{3}\right)$ \\
Det P & $0.016\left(\mathrm{gP} / \mathrm{m}^{3}\right)$ \\
$\mathrm{NH}_{4}$ & $0.070\left(\mathrm{gN} / \mathrm{m}^{3}\right)$ \\
$\mathrm{NO}_{3}$ & $0.070\left(\mathrm{gN} / \mathrm{m}^{3}\right)$ \\
$\mathrm{PO}_{4}$ & $0.124\left(\mathrm{gP} / \mathrm{m}^{3}\right)$ \\
$\mathrm{OXY}$ & $8.0\left(\mathrm{~g} / \mathrm{m}^{3}\right)$ \\
\hline
\end{tabular}

表 5 境界条件

\begin{tabular}{|l|l|}
\hline \multicolumn{1}{|c|}{ 変数 } & \multicolumn{1}{|c|}{ 值 } \\
\hline Green & $0.5\left(\mathrm{gC} / \mathrm{m}^{2}\right)$ \\
Det C & $0.6\left(\mathrm{gC} / \mathrm{m}^{3}\right)$ \\
Det $\mathrm{N}$ & $0.096\left(\mathrm{gN} / \mathrm{m}^{3}\right)$ \\
Det P & $0.012\left(\mathrm{gP} / \mathrm{m}^{3}\right)$ \\
$\mathrm{NH}_{4}$ & $0.025\left(\mathrm{gN} / \mathrm{m}^{3}\right)$ \\
$\mathrm{NO}_{3}$ & $0.025\left(\mathrm{gN} / \mathrm{m}^{3}\right)$ \\
$\mathrm{PO}_{4}$ & $0.020\left(\mathrm{gP} / \mathrm{m}^{3}\right)$ \\
$\mathrm{OXY}$ & $8.0\left(\mathrm{~g} / \mathrm{m}^{3}\right)$ \\
\hline
\end{tabular}

表 6 流入負荷量

\begin{tabular}{|l|r|r|r|r|r|r|r|r|r|}
\hline & 流量 & Green & Det $\mathrm{C}$ & Det $\mathrm{N}$ & Det $\mathrm{P}$ & $\mathrm{NH}_{4}-\mathrm{N}$ & $\mathrm{NO}_{3}-\mathrm{N}$ & $\mathrm{PO}_{4}-\mathrm{P}$ & $\mathrm{OXY}$ \\
\hline \multicolumn{1}{|c|}{ 単位 } & \multicolumn{1}{|c|}{$\mathrm{m}^{3} / \mathrm{s}$} & \multicolumn{7}{|c|}{$\mathrm{t} / \mathrm{day}$} \\
\hline 荒川 & \multicolumn{1}{|c|}{218.25} & 0 & 15.3 & 0 & 0 & 38.8 & 38.8 & 3.90 & 20.0 \\
\hline 隅田川 & 14.34 & 0 & 1.8 & 0 & 0 & 0.6 & 0.6 & 0.53 & 45.4 \\
\hline 多摩川 & 61.45 & 0 & 10.5 & 0 & 0 & 29.5 & 29.5 & 4.63 & 37.8 \\
\hline 鶴見川 & 16.98 & 0 & 5.2 & 0 & 0 & 10.9 & 10.9 & 3.02 & 0.002 \\
\hline 旧江戸川 & 198.35 & 0 & 10.6 & 0 & 0 & 16.2 & 16.2 & 3.90 & 47.2 \\
\hline 江戸川放水路 & 2.62 & 0 & 11.4 & 0 & 0 & 18.4 & 18.4 & 3.68 & 56.0 \\
\hline
\end{tabular}

\section{5.おわりに}

本研究では、東京湾を対象に浮遊系と底泥系を結合した生態系モデルを開発し、夏季の水質の再現計算を行った。 その結果、概ね実測データと一致した結果が得られ、東京湾の最も深刻な問題である底層の貧酸素水塊の形成がシミ ユレートできた。

今後はより詳細な検討を継続すると共に、各種プロジェクトに際しての環境影響評価を行っていきたいと考えてい る。 
表 7 モデルパラメータの值

\begin{tabular}{|c|c|c|c|c|c|c|c|c|}
\hline 変数 & 值 & 単位 & 変数 & 值 & 単位 & 変数 & 值 & 単位 \\
\hline PPMAX & 1.8 & (/d) & $\mathrm{KmP}$ & 0.003 & $\left(\mathrm{gP} / \mathrm{m}^{3}\right)$ & Cunvat & 1.0 & \\
\hline Mresp & 0.045 & (/d) & $\mathrm{RAD}_{\text {sat }}$ & 96.5 & $\left(\mathrm{~W} / \mathrm{m}^{2}\right)$ & ZMinDetC & 0.0 & $\left(\mathrm{~g} / \mathrm{m}^{3} / \mathrm{d}\right)$ \\
\hline Gresp & 0.15 & & TFGro & 1.0 & & ZMinDet N & 0.0 & $\left(\mathrm{~g} / \mathrm{m}^{3} / \mathrm{d}\right)$ \\
\hline Mort0 & 0.35 & (/d) & Znit & 0.0 & $\left(\mathrm{gN} / \mathrm{m}^{3} / \mathrm{d}\right)$ & ZMinDetP & 0.0 & $\left(\mathrm{~g} / \mathrm{m}^{3} / \mathrm{d}\right)$ \\
\hline TFMrt & 1.0 & & RcNit & 0.15 & (/d) & RCDetC & 0.12 & (/d) \\
\hline MrtSed & 3.0 & (/d) & TcNit & 1.07 & & RCDetN & 0.08 & (/d) \\
\hline NCRat & 0.16 & $(\mathrm{gN} / \mathrm{gC})$ & OOXNit & 5.0 & $\left(\mathrm{~g} / \mathrm{m}^{3}\right)$ & RCDetP & 0.08 & (/d) \\
\hline PCRat & 0.02 & $(\mathrm{gP} / \mathrm{gC})$ & COXNit & 1.0 & $\left(\mathrm{~g} / \mathrm{m}^{3}\right)$ & TCDetC & 1.047 & \\
\hline $\mathrm{NH}_{4}$ Krit & 0.01 & $\left(\mathrm{gN} / \mathrm{m}^{3}\right)$ & CTNit & 3.0 & $\left({ }^{\circ} \mathrm{C}\right)$ & TCDetN & 1.047 & \\
\hline FrAut & 0.3 & & CFLNit & 0.0 & & TCDetP & 1.047 & \\
\hline FrDet & 0.7 & & CunvNit & 0.0 & & CTMin & 3.0 & \\
\hline TCGro & 1.04 & & ZDenWat & 0.0 & $\left(\mathrm{gN} / \mathrm{m}^{3} / \mathrm{d}\right)$ & ExtVLBak & 0.127 & $(/ \mathrm{m})$ \\
\hline TCDeC & 1.07 & & RcDenWat & 0.0 & (/d) & ExtVLGreen & 0.15 & $\left(\mathrm{~m}^{2} / \mathrm{gC}\right)$ \\
\hline OptDL & 0.58 & (d) & TcDenWat & 1.07 & & ExtVLDetC & 0.06 & $\left(\mathrm{~m}^{2} / \mathrm{gC}\right)$ \\
\hline DayL & 0.58 & (d) & OOXDEN & 1.0 & $\left(\mathrm{~g} / \mathrm{m}^{3}\right)$ & VOSedGreen & 0.1 & (m/day) \\
\hline $\mathrm{PrfNH}_{4}$ & 1.0 & & COXDEN & 3.0 & $\left(\mathrm{~g} / \mathrm{m}^{3}\right)$ & VOSedDet & 0.423 & (m/day) \\
\hline KmDIN & 0.042 & $\left(\mathrm{gN} / \mathrm{m}^{3}\right)$ & CTDen & 2.0 & $\left({ }^{\circ} \mathrm{C}\right)$ & Dx、Dy & 40 & $\left(\mathrm{~m}^{2} / \mathrm{s}\right)$ \\
\hline
\end{tabular}

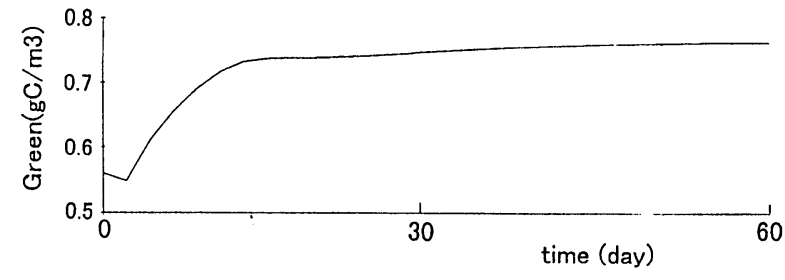

（a）植物プランクトン

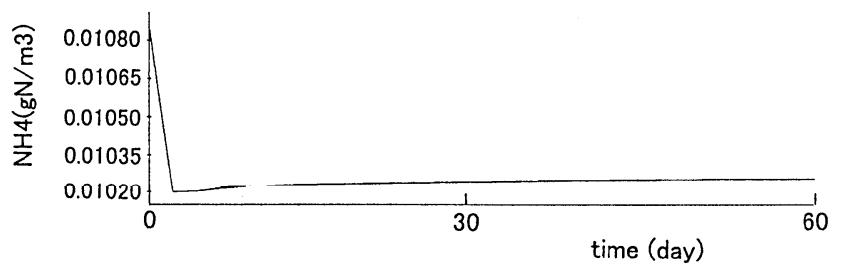

（c）アンモニア態窒素

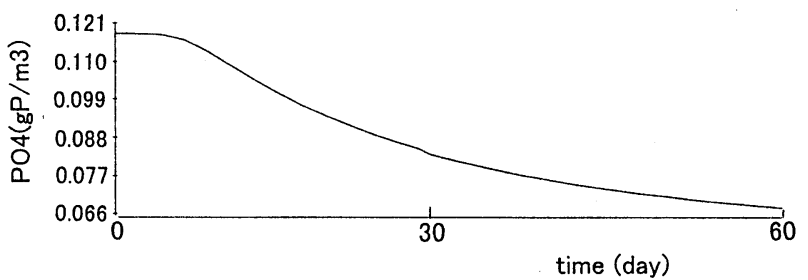

（b）リン酸態リン

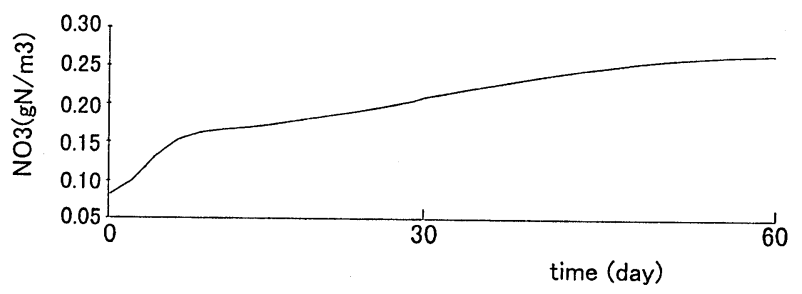

（d）硝酸態窒素

図 3 モニター点での水質指標の時系列

参考文献

田中昌宏・G.S.Stelling・A.Markus (1996)；東京湾の残差流のシミュレーションとそれが水質解析に及ぼす影響に

ついて、海岸工学論文集、第 43 巻、pp. 1121-1125.

堀口文男・中田喜三郎 (1995)：東京湾の水質のモデル解析、J. Adv. Mar. Sci. and Tech. Soc., Vol.1, pp.71-93.

一都三県公害防止協議会 (1996)：東京湾水質污濁調査報告書、平成 6 年度、p. 34 .

Nakata, $\mathrm{K}$ and T.Kuramoto(1992):A model of the formation of oxygen depleted waters in Tokyo Bay, Proc. Adv.

Mar. Tech. Conf., Vol.5, pp.107-132. 


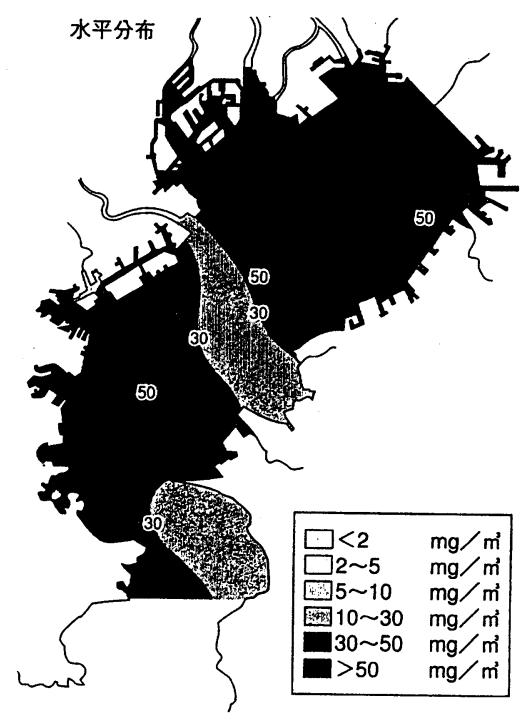

(a ）クロロフィル a

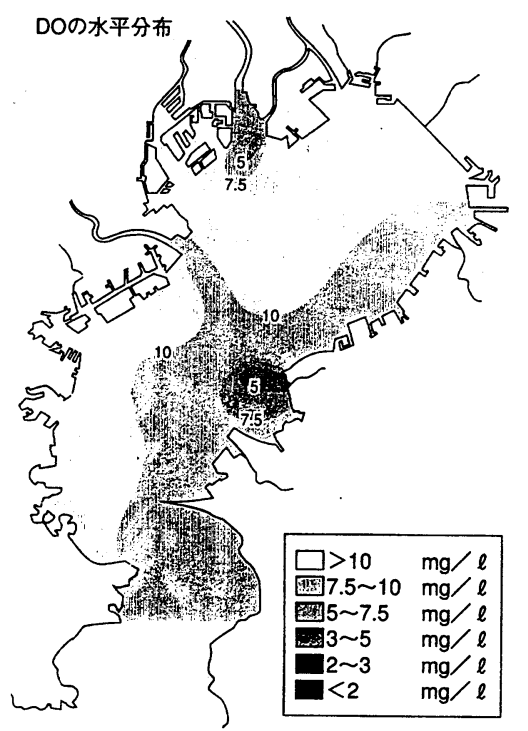

(b) 溶存酸素 (上層)

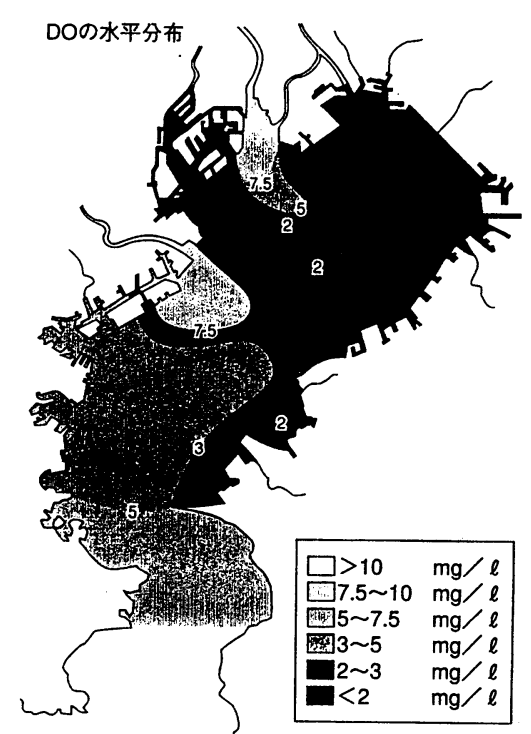

（c）溶存酸素(底層)

図 4 公共皮域データによる 1994 年 7 月の水質分布

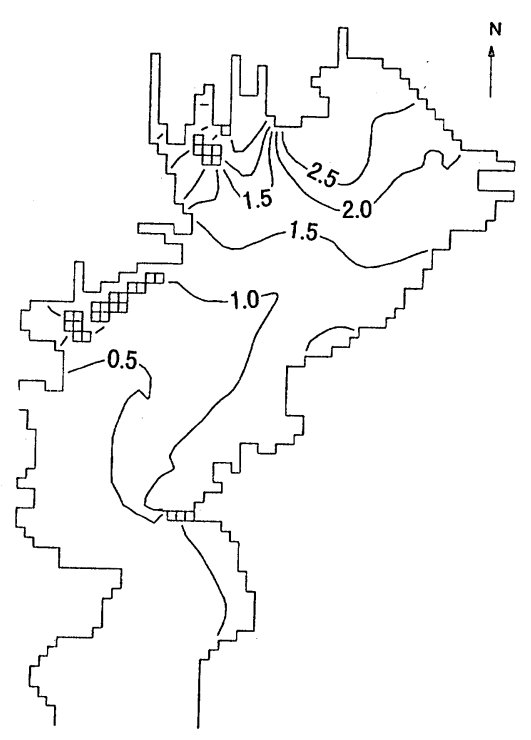

（a）植物プランクトン $\left(\mathrm{gC} / \mathrm{m}^{3}\right)$

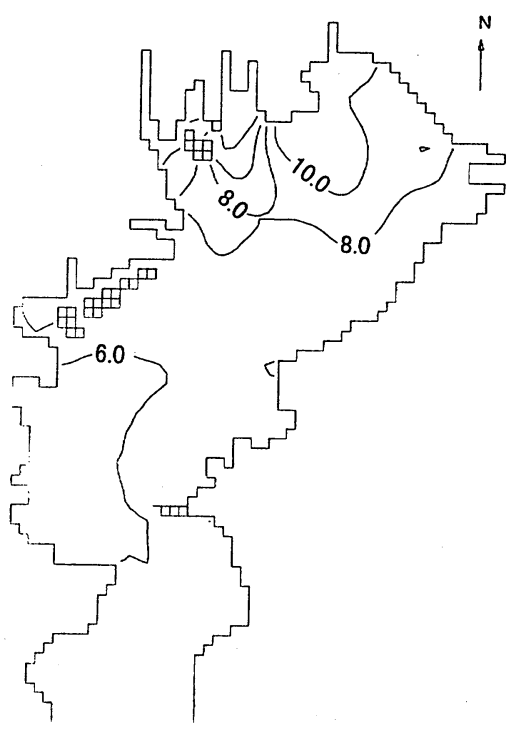

(b) 溶存酸素 (上層) $\left(\mathrm{g} / \mathrm{m}^{3}\right)$

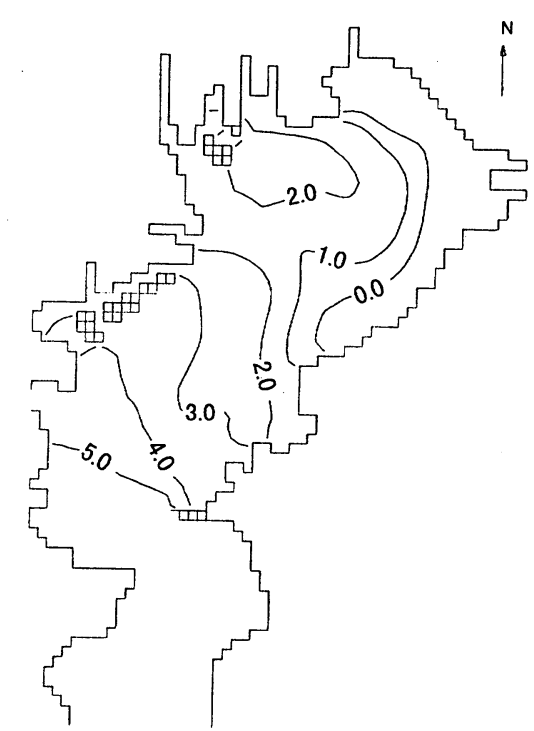

(c) 溶存酸素 (底層) $\left(\mathrm{g} / \mathrm{m}^{3}\right)$

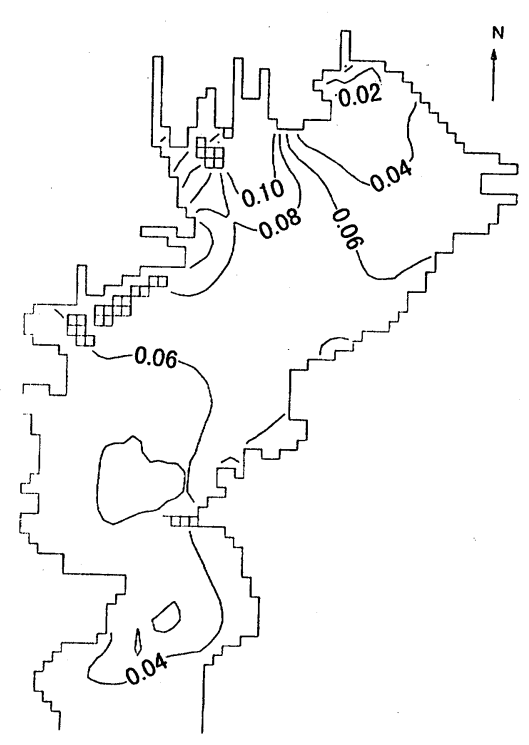

(d)リン酸態リン $\left(\mathrm{gP} / \mathrm{m}^{3}\right)$

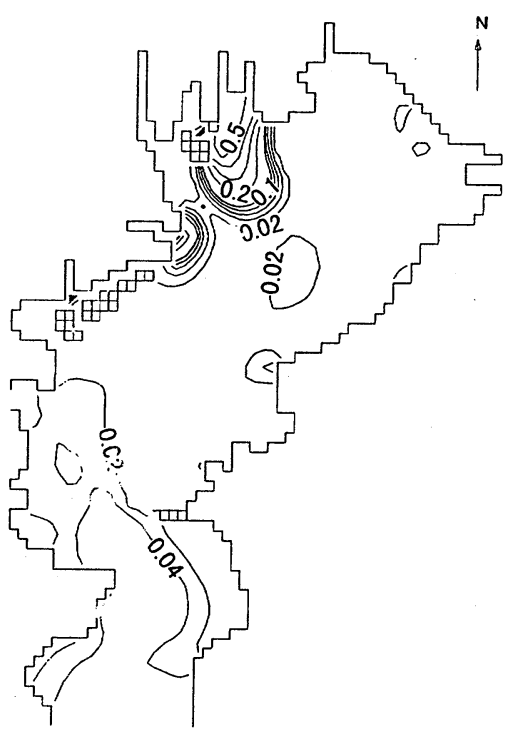

(e ) アンモニア態窒素 $\left(\mathrm{gN} / \mathrm{m}^{3}\right)$

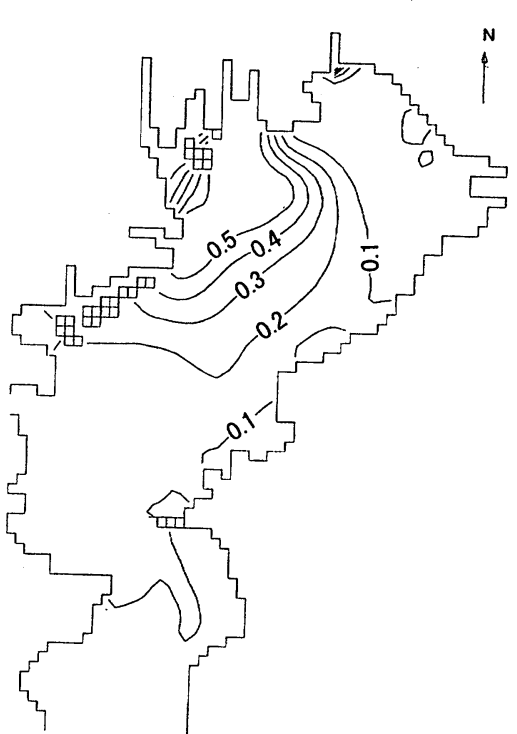

（f）硝酸態窒素 $\left(\mathrm{gN} / \mathrm{m}^{3}\right)$

図 5 計算結果 (60日目の上層の濃度分布) 